\title{
Predicting green product consumption using theory of planned behavior and reasoned action
}

\author{
Daru Asih $^{\mathrm{a}}$, Made Setini ${ }^{\mathrm{b}}$, Mochamad Soelton ${ }^{\mathrm{a}}$, Nilna Muna ${ }^{\mathrm{b}}$, I Gede Cahyadi Putra ${ }^{\mathrm{c}}$, Dio Caesar Darma ${ }^{\mathrm{d}}$ \\ and Justina Ade Judiarni ${ }^{\mathrm{e}}$
}

${ }^{a}$ Faculty of Economic and Business, Universitas Mercu Buana, Jakarta, Indonesia

${ }^{b}$ Ph.D Faculty of Economics and Busines, Udayana University, Bali, Indonesia

${ }^{c}$ Faculty of Economic and Business, Mahasaraswati University, Bali, Indonesia

${ }^{d}$ Faculty of Management, Samarinda High College of Economics Science, Samarinda, Indonesia

${ }^{e}$ Faculty of Economic and Busines, Mulawarman, Samarinda, Indonesia

\section{H R O N I C L E}

Article history:

Received: April 29, 2020

Received in revised format:

April 302020

Accepted: May 30, 2020

Available online:

May 30, 2020

Keywords:

Knowledge

Environmental Concern

Attitudes

Norms

Behavior

Green Products

Planned Behavior

\section{A B S T R A C T}

The program to reduce plastic waste is supported by all sectors of businesses, through some efforts to prevent using plastic bags in every store shopping and prompt using better alternatives. This study aims to find out whether the application of the theory of planned behavior departs from the knowledge of the influence of environmental awareness and leads to interest in the use of reusable bags. Quantitative methods used in this study includes the determination of samples with non-probability techniques, namely purposive sampling. The research instrument was an online questionnaire of 300 respondents in Bali, who had never used a repetitive shopping bag. Data were analyzed using Structural Equation Modeling with the SmartPLS application. The application of the theory of planned behavior shows that testing knowledge of the environment and environmental stewardship gives a positive attitude and becomes a control behavior and interest in the use of reusable bag products. However, it is different from Subjective Norms which do not have a significant influence on the interest in using reusable bags. So, it is a concern for the government to always provide socialization, knowledge and environmental awareness about the importance of protecting the environment by using non-disposable shopping bags, and also business owners or marketing management to provide more reusable bags.

\section{Introduction}

Plastic waste becomes a polemic of the world because it is a trigger for global warming (Luke, 2019). Increasing the production of plastic waste between 1996 and now has damaged the environment, especially pollution of the marine environment (Handl, 2019). This is a phenomenon that has always been the subject of discussion, where until now waste has continued to increase without the right solution (Yang et al., 2017). Waste is one of the serious problems faced by the Indonesian state and arises due to a large number of Indonesia's population (Addahlawi et al., 2019). This is due to the fact of a big population of the country are presently creating huge amount of wastes (Yang et al., 2017). The serious problem is the impact caused by waste, especially plastic waste such as body health, the environment, air, and sea pollution. Plastic waste is the toughest waste problem because plastic is very difficult to be decomposed naturally, and also plastic is made from materials that are harmful to the environment and living things (Gallo et al., 2018; Ilman et al., 2017). Indonesia itself continues to experience an increase in plastic waste due to the use of-based plastic products (Yuliadi, 2017), in addition to that buying or delivering something is always plastic mediated so this makes the volume of plastic waste increase especially in Jakarta (Nasution et al. , 2019), and Bali which is the center of Bali's tourist city (Putri, 2019). For Bali, the Governor of Bali issued Bali Governor Regulation No. 97 of 2018 on limiting the generation of disposable plastic waste to achieve a reduction in plastic waste of up to $70 \%$ within the next year, which brings the concept of local wisdom "Nangun Sat Kerthi Loka Bali", arranging a green, * Corresponding author.

E-mail address: Gitan4nd4@gmail.com (M. Setini) 
beautiful and clean environment and the environment to preserve Bali's majesty, sanctity, and nature, while in Jakarta the regulation of Law No. 108 of 2019 concerning household waste. To support the reduction in the use of plastic waste, the Government of Indonesia has issued Presidential Regulation (Perpres) No. 83 of 2018 to reduce the use of plastic in shopping centers (Sipuu.setkab.go.id). Furthermore, with the existence of the circular it was hoped that all modern stores and shopping centers could disseminate to consumers gradually. So that in 2019 all modern stores and shopping centers will no longer use plastic bags and other plastic materials. In addition to modern shops and shopping centers, there is also a need for public awareness to help sort waste and make use of maximized garbage banks. Also, to reduce plastic waste, the Government called on to replace the use of plastic bags by the use of eco-friendly bags or shopping bags that can be used again (reusable). Based on phenomena and problems, the object of this research is the interest in using shopping bags reusable in Indonesian society.

\section{Literature Review and Hypothesis Development}

\subsection{Theory of planned behavior}

The theory of planned behavior is to combine additional dimensions of behavioral control perceptions as determinants of behavioral intentions (Ajzen, 1991). The theory of planned behavior has been applied to the study of the relationship between attitudes toward behavior, subjective norms, and perceptions of behavioral control, behavioral intentions and behaviors in various fields such as advertising, public relations, campaigns, health, and others. The intention is the most important supporter of human behavior, always being able to utilize information is the rational side of being human (Paul et al., 2016).

\subsection{Interests of users of green products}

Interest in the use of green products is the stage in which consumers tend to act before buying decisions are implemented (Das, 2014; Maniatis, 2016; Zhang et al., 2019). Consumers to use certain products will show a higher level of purchase compared to consumers who indicate that they have no intention to buy (Hong et al., 2017; Moslehpour et al., 2018).

\subsection{The Behavior}

Control of behavior can be divided into three categories (Wu et al., 2017); namely (1). Attitudes, these attitudes are grouped into three things; namely: perceptions and knowledge about problems from the environment (a cognitive component), feelings or emotions that arise in the environment (an affective component), and a tendency to behave or act towards the environment (a conative component) (Alsaggaf \& Althonayan, 2018). Where the attitude towards behavior is believed to be someone's belief that emerges (behavioral beliefs), which represents the perception of the consequences of behavior and evaluation of the significance of the consequences (Han et al., 2010). (2). Subjective norms is the second determinant of behavioral intentions (Ajzen, 1991). Subjective norms are represented as a function of normative beliefs about important references that an individual should or should not do, and his motivation for following their referents (Ajzen, 1991; Wu et al., 2017). (3). Behavioral control perception, the third determinant of behavioral intentions is behavioral control. Behavioral control perceptions can be described as the perceptions of ease or difficulty in behavior (Ajzen, 1991; Paul et al., 2016). Specifically, behavioral control perceptions assess the perception of how well a person can control the factors that can facilitate or limit the actions needed to deal with certain situations. According to Alsaggaf and Althonayan (2018), the perception of behavioral control is the ease or obstacles perceived by consumers in making purchases or the use of green products.

\subsection{Environmental Knowledge}

Knowledge is a set of ecological knowledge possessed by individuals about the environment (Zhang et al., 2019) while Maichum et al. (2016) and Attia and Farrag (2017) believe that knowledge about ecology is a basic knowledge possessed by a consumer about things that can be done to assist in environmental protection activities that are facilitated by behavioral commitments to purchase green products.

\subsection{Environmental Concern}

Care is a predictive tool that allows for the behavior of purchasing environmentally friendly products and can be a major factor in the consumer decision-making process (Angelovska et al., 2012; Attia \& Farrag (2017). Environmental care is considered as a level of commitment and emotional towards various environmental issues (Aman et al., 2012; Zhang et al., 2019).

\subsection{Environmental Knowledge Relations, Environmental Concern, and Behavioral Control, Interest in Green Products}

Interests in using or buying intentions can be used to predict future behavior. This means that if a consumer shows a high purchase intention, it can be assumed that he will make an actual purchase. Therefore, marketers have an interest in identifying consumer purchase intentions (Suprapti, 2010; Zhang et al., 2019). Behavioral control plays an important role in determining interest in green products as stated by Noor et al. (2012) and Al Mamun et al. (2018). More clarified by a statement by Groening et al. (2018) which says that attitudes towards the environment are general tendencies that occur in a person and are formed or studied when responding consistently/surely to the state of the environment in the form of likes (positive) or dislike (negative). Subjective norms as perceptions of social pressure to do or not do the behavior, or opinions that others feel 
are significant/important to individuals and that influence them in decision making (Park, 2000; Attia \& Farrag (2017). Behavioral control perception is a function of control beliefs which refers to one's perception of the presence or absence of resources or opportunities needed to perform certain behaviors (Ajzen in Han et al., 2010; Al Mamun et al., 2018). Knowledge of the environment can influence consumer attitudes. With the higher level of environmental knowledge and attention possessed by a consumer, higher ecological attitude is possessed when consumer is compared with other consumers who do not have knowledge and attention to the environment which in turn affects their ecological behavior (Zhang et al., 2019). According to Julina (2013) and Xu et al. (2017), concern or attention to environmental issues can affect attitudes. Some consumers translate their concern for the environment by choosing green products to improve the quality of the environment and the quality of their lives (Novandari, 2011). Aman et al. (2012) and Al Mamun et al. (2018) say that environmental care can be a major factor in the consumer decision-making process. So, the relationship between these variables can be drawn the following hypothesis:

H1: Environmental Knowledge has a positive effect on Environmental Attitudes.

H2: Environmental Concern has a positive effect on Environmental Attitudes.

H3: Environmental Concern has a positive effect on Subjective Norms.

H4: Environmental Concern has a positive effect on The perception of Control.

H5: Environmental Attitudes positive influence on Green Product.

H6: Subjective Norms influence positively to the Green Product.

H7: Perception of Control positive influence on Green Product.

H8: Environmental Knowledge influence positively to the Green Product.

Based on theoretical and study results from previous studies to look like the concepts in Fig. 1.

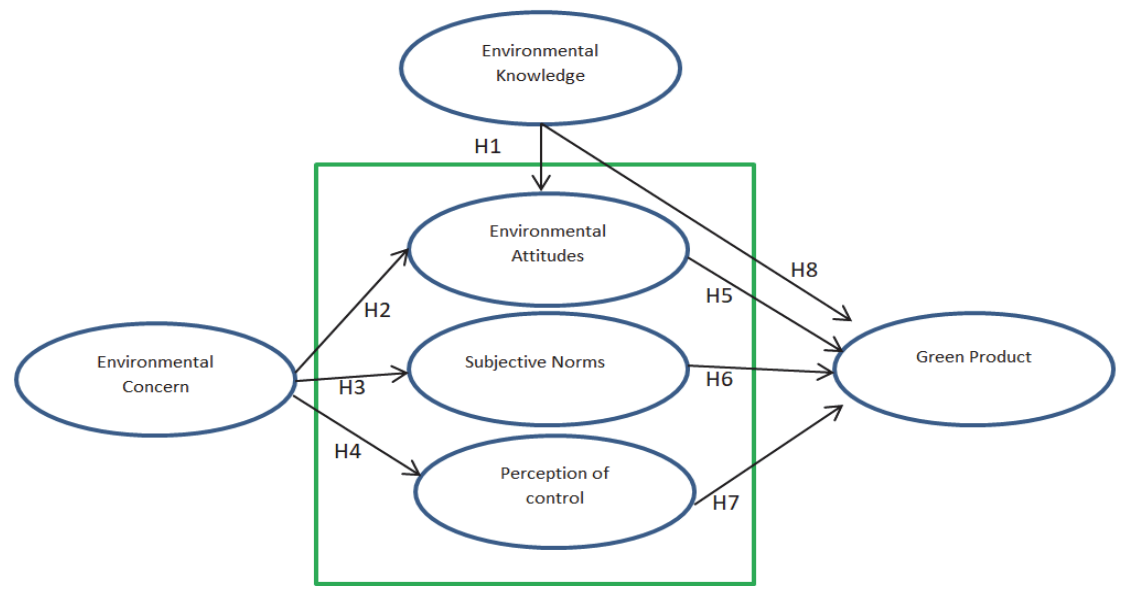

Fig. 1. Research Concept Framework

Source: author's processed results, 2020.

\section{Method}

The population of this study is the people of Indonesia with the sample used is non-probability sampling. The sample of research respondents used amounted to 150 samples since according to Hair et al. (2017), the number of samples used needs to be 5 to 10 times multiplied by the indicator so that the 300 sample is sufficiently representative. This study uses SEM-PLS analysis techniques with the SmartPLS application as data processing. There are two fundamental model evaluations in this test, namely the outer model and the inner model. The reason for using PLS is to help researchers for predictive purposes (Ghozali, 2015). PLS uses a three-stage iteration process and each iteration stage produces an estimate.

\section{Results}

Conversion validity with reflective indicators can be seen from the correlation between score indicators and external loading variables. A score of $>$ AVE 0.50 or greater indicates the model is good and all constructs used in this study have adequate discriminant validity. Likewise, discriminant validity is used to assess the validity of variables from the average variance extracted (AVE) value. The model is said to be good if the AVE of each variable's value is greater than 0.50 . In addition to the validity test, a variable reliability test is also measured by two criteria, namely composite reliability and Cronbach's alpha of the indicator block measuring variables. Cronbach's Alpha values are required above 0.60, as well as the significance at the $5 \%$ test ( $\mathrm{t}$-statistic value $>1.96$ or $\mathrm{p}$-Value $<0.5$ ). The composite reliability value $(\mathrm{CR})$ of each construct is all expected to be more than 0.7 to fulfill. The results of the correlation between indicators and variables can be seen in Table 1 below. 
Table 1

Test the validity and reliability of

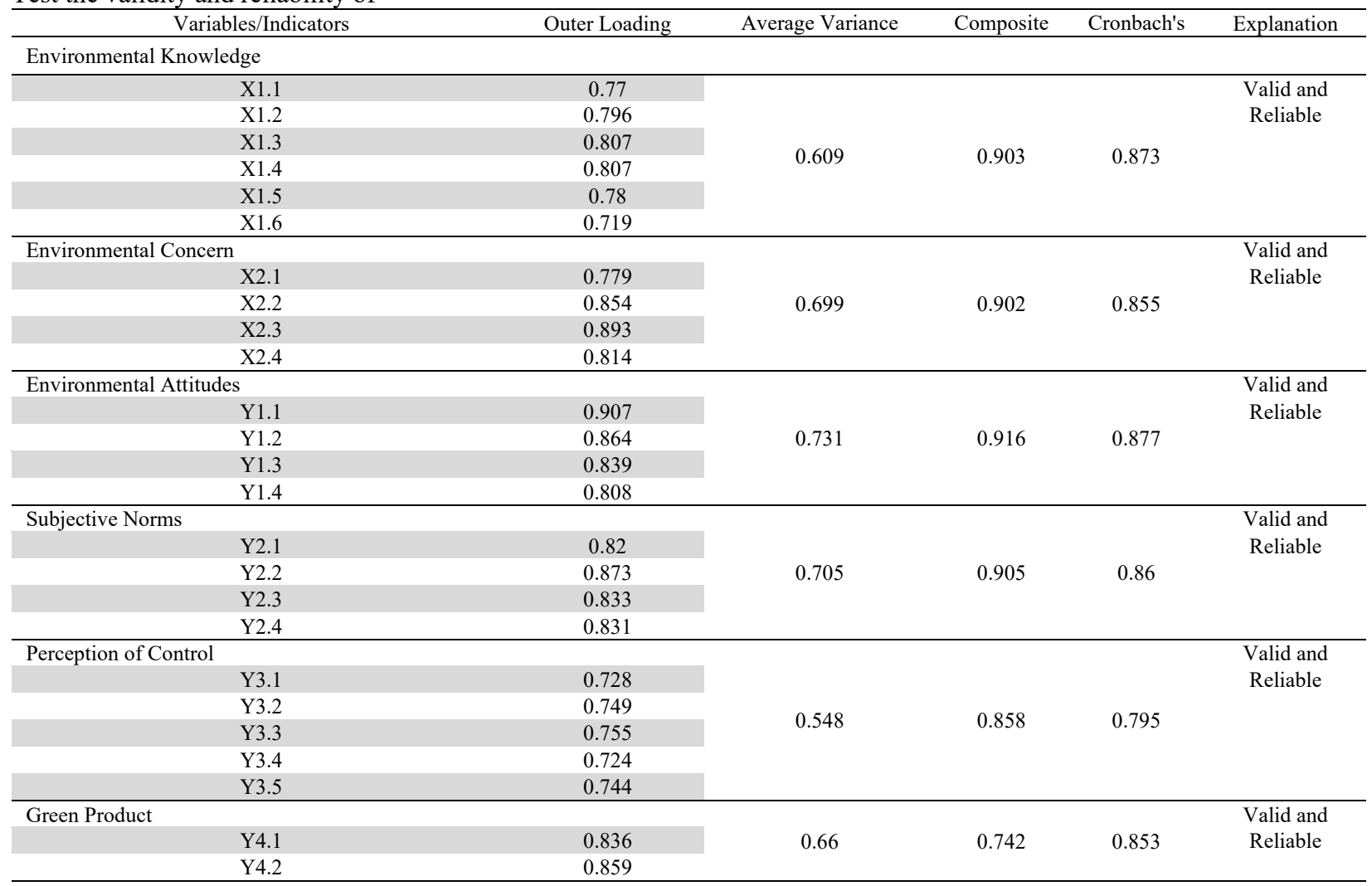

In this structural model, there are two dependent variables, namely: attitude, subjective norm, perceived behavioral control and interest in the use green product the coefficient of determination $\left(\mathrm{R}^{2}\right)$ of each ma sing bound variables can be presented in Table 2 as follows.

Table 2

Value Coefficients of R-square

\begin{tabular}{ccc}
\hline Variable & R-square & Adjusted \\
\hline Environmental Attitudes (Y1) & 0.603 & 0.595 \\
Subjective Norms (Y2) & 0566 & 0561 \\
Perception of Control (Y3) & 0530 & 0525 \\
Green Product (Y4) & 0780 & 0768 \\
\hline
\end{tabular}

Based on Table 2, the effect of Environmental Knowledge gives the R-square of 0.603 which can be interpreted that the variability of the variable attitude can be explained by the variability the environmental knowledge variable is 60.3 percent, while 39.7 percent is explained by other variables outside the study. Furthermore, the influence of environmental awareness on subjective norms gives an $R$-square value of 0.566 which can be interpreted that the variability of subjective norm variables can be explained by the variability of environmental awareness variables by 56.6 percent, while 43.4 percent is explained by other variables outside of the study. Then, the model of the influence of environmental awareness on behavioral control perceptions gives an $R$-square value of 0.530 which can be interpreted that the variability of behavioral control perception variables can be explained by the variability of environmental awareness variables by 53 percent, while 47 percent is explained by other variables outside the study. And finally, the model of the influence of environmental knowledge, environmental awareness, attitudes, subjective norms and perceptions of behavioral control on the interest in using green products gives an $R$-square value of 0.780 which can be interpreted that the variability of behavioral control perception variables can be explained by the variability of interest variables in the use of green products by 78 percent, while 22 percent is explained by other variables outside of the study. To measure how well the observational values generated by the model and also the estimated parameters, it is necessary to calculate $Q$-square $\left(\mathrm{Q}^{2}\right)$ as follows:

$\mathrm{Q} 2=1-(1-\mathrm{R} 12)(1-\mathrm{R} 22)(1-\mathrm{R} 32)(1-\mathrm{R} 42)=1-0.0178=0.9822$

The value of $\mathrm{Q}^{2}$ has a value in the range $0<\mathrm{Q}^{2}<1$, where the closer to 1 means the better the model. The calculation results obtained value of $\mathrm{Q}^{2}$ is equal to 0.9822 , so it can be concluded that the model has predictive relevance. Thus, it can be 
explained that 98.22 percent of the variation in the interest in using bags reusable in Denpasar City is influenced by environmental knowledge, environmental awareness, attitudes, subjective norms and perceptions of behavioral control, while the remaining 1.78 percent is influenced by other variables.

\section{Discussion}

Testing the direct effect between variables in detail can also be seen from the results of the path coefficient validation test on each path from the test results bootstrapping as shown in Fig. 2 and Table 3 below.

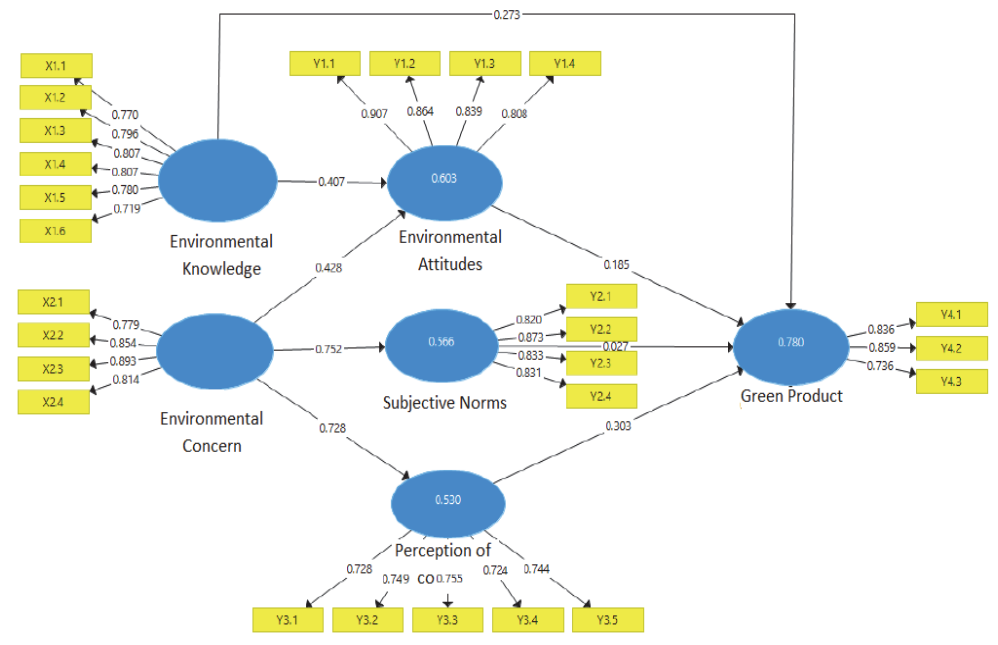

Fig. 2. Measurement Model of PLS Results.

Source: Authors' calculations

Table 3

Path Coefficients

\begin{tabular}{lcccc}
\multicolumn{1}{c}{ Between Path Variables } & Coefficient & $\boldsymbol{t}$ Statistics & $\boldsymbol{p}$-Value & \multicolumn{1}{c}{ Information } \\
\hline Environmental Knowledge $\rightarrow$ Environmental Attitudes & 0.407 & 4,109 & 0,000 & Positive and Significant \\
Environmental Concerns $\rightarrow$ Environmental Attitudes & 0.428 & 4,318 & 0,000 & Positive and Significant \\
Environmental Concerns $\rightarrow$ Subjective Norms & 0.752 & 16,038 & 0,000 & Positive and Significant \\
Environmental Concerns $\rightarrow$ Perception of Control & 0.728 & 17,154 & 0,000 & Positive and Significant \\
Environmental Knowledge $\rightarrow$ Green Product & 0.273 & 2.627 & 0.009 & Positive and Significant \\
Environmental Attitudes $\rightarrow$ Green Product & 0.185 & 2,361 & 0.019 \\
Subjective Norms $\rightarrow$ Green Product & 0.027 & 0.343 & 0.732 & Positive and Significant \\
Perception of Control $\rightarrow$ Green Product & 0.303 & 3,605 & 0,000 \\
\hline
\end{tabular}

Based on the results of the path coefficients in Table 3, the hypothesis testing results can be determined which are described in the following description:

\subsection{The influence of environmental knowledge on Environmental Attitudes}

Based on the results of the analysis of the influence of environmental knowledge on attitudes we have obtained a $p$ value of 0,000 ( $p$ value $<0.05$ ), with a t-statistic of 4.109 (t-statistic $>1.96$ ) and a positive path coefficient of 0.407 . This indicates that $\mathrm{H} 1$ is accepted, which means that environmental knowledge has a positive and significant effect on consumer attitudes in buying green products. The result of the study means that the higher the environmental knowledge, the better attitude of consumers towards the environment. With the intense information from print media advertisements and television carried out by the Indonesian government we may provide many insights for the public about the dangers of plastic waste. In line with research conducted by Al Mamun et al. (2018) and Groening et al. (2018).

\subsection{The influence of environmental concern on Environmental Attitudes}

Based on the results of the analysis of the influence of environmental awareness on attitudes we have obtained a $p$-value of 0.000 ( $p$-value $<0.05)$, with a t-statistic of 4.318 (t-statistic $>1.96)$ and a positive path coefficient of 0.428 . This indicates that $\mathrm{H} 2$ is accepted, which means that environmental care has a positive and significant effect on consumer attitudes in buying green products. The results of the study have the meaning that an increase on consumers about environmental problems will results positive attitude of consumers towards the environment and this is in line with the previous results (Park, 2000; Attia $\&$ Farrag, 2017). The community must realize the importance of keeping the environment clean with a positive attitude such as throwing trash in its right place, by first sorting according to the type of waste. 


\subsection{The influence of environmental concern on subjective norms}

Based on the results of the analysis of the influence of environmental awareness on subjective norms we have obtained a $p$ value of 0.000 ( $p$-value $<0.05$ ), with a t-statistic of 16.038 (t-statistic $>1.96$ ) and a positive path coefficient of 0.752 . This indicates that $\mathrm{H} 3$ is accepted, which means that environmental care has a positive and significant effect on subjective norms. The result of the study means that the higher the consumer's concern on environmental problems, the bigger the influence of subjective norms and this result is supported by Han et al., 2010).

\subsection{The influence of environmental awareness on behavioral control perceptions}

Based on the results of the analysis of the influence of environmental awareness on behavioral control perceptions we have obtained $p$-value of 0,000 ( $p$-value $<0.05$ ), with a t-statistic of 17,154 (t-statistic $>1.96$ ) and a positive path coefficient value of 0.728 . This indicates that H4 is accepted, which means that environmental care has a positive and significant effect on perceptions of behavioral control. The results of the study mean that the higher the consumer's concern for environmental problems, the higher the perception of behavioral control and this result is supported by Al Mamun et al. (2018).

\subsection{Effect of environmental knowledge on the interest in using green products}

Based on the results of the analysis of the influence of environmental knowledge on the interest in using green products, the p-value is 0.009 ( $p$-value $<0.05$ ), with statistics of 2.627 (t-statistic $>1.96$ ) and a positive path coefficient of 0.273 . This indicates that $\mathrm{H} 5$ is accepted, which means that environmental knowledge has a positive and significant effect on the interest in using green products. The results of the study mean that the higher the environmental knowledge, the interest of consumers to use green products will increase and the results is consistent with findings of Groening et al. (2018).

\subsection{Effect of attitude towards an interest in using green products}

Based on the results of the analysis of the influence of attitudes on the interest in using green products, we have found the $p$ value of 0.019 ( $p$-value $<0.05)$, with a t-statistic of 2.361 (t-statistic $>1.96$ ) and a positive path coefficient of 0.185 . This indicates that $\mathrm{H} 7$ is accepted, which means that attitude has a positive and significant effect on the interest in using green products. The results of the study have the meaning that the more positive the attitude of consumers to the environment, the higher interest of consumers using green products and the result is supported by Aman et al. (2012).

\subsection{Effect of subjective norms on the interest in using green products}

Based on the results of the analysis of the influence of subjective norms on the interest in using green products, the $p$ value is 0.732 ( $p$ value $>0.05$ ), with a t-statistic of 0.343 ( $\mathrm{t}$-statistic $<1.96$ ) and a positive path coefficient value of 0.027 . This indicates that $\mathrm{H} 8$ is rejected, which means that subjective norms do not significantly influence the interest in using green products. The results of the study mean that the level of subjective norms accepted by consumers is not able to influence consumer interest in using green products, and the results is supported by Al Mamun et al. (2018).

\subsection{The effect of behavioral control perceptions on the interest in using green products}

Based on the results of the analysis of the influence of behavioral control perceptions of interest in the use of green products, we have obtained $p$-value of 0.000 ( $p$-value $<0.05$ ) with a t-statistic of 3.605 (t-statistic $>1.96)$ and a positive path coefficient of 0.303 . This indicates that H9 is accepted, which means that perceptions of behavioral control have a positive and significant effect on interest in using green products. The results of the study mean that the higher the perception of behavioral control, the higher the interest of consumers using green products and this is in line with the research of Attia \& Farrag (2017).

\section{Conclusions and Recommendations}

Based on the discussion of research that has been perform in this survey, it can be concluded that with the increase of knowledge about protecting the environment and with an increase awareness of the environment, we may expect a better and clean environment. However, subjective norm does not seem to have any meaningful effect in using green products, which means that the perceived social pressure of people who are considered important around consumers would not have any meaningful influence to press for any action, since respondents tend to have high environmental knowledge and awareness. Governments and business organizations play an important role in implementing green product programs, so there is a need for a collaboration. For future research there needs to be a review on the role of business organizations on green product policies for sustainable business.

\section{References}

Ajzen, I. (1991). The theory of planned behavior. Organizational Behavior, and Human Decision Processes, 50(2), $179-211$. 
Addahlawi, H.A., Mustaghfiroh, U., Ni'mah, L.K., Sundusiyah, A., \& Hidayatullah, A.F. (2019). IMPLEMENTASI PRINSIP GOOD ENVIRONMENTAL GOVERNANCE DALAM PENGELOLAAN SAMPAH DI INDONESIA. Jurnal Green Growth dan Manajemen Lingkungan, 8, 106-18.

Attia, S., \& Farrag, M. (2017). The effect of Egyptian consumer values \& lifestyles on green purchase behavior. Journal of Marketing Development \& Competitiveness, 11(4).

Al Mamun, A., Mohamad, M. R., Yaacob, M. R. B., \& Mohiuddin, M. (2018). Intention and behavior towards green consumption among low-income households. Journal of Environmental Management, 227, 73-86

Alsaggaf, M. A., \& Althonayan, A. (2018). An empirical investigation of customer intentions influenced by service quality using the mediation of emotional and cognitive responses. Journal of Enterprise Information Management.

Aman, A.H.L., Amran H., \& Zuhal H. (2012). The influence of environmental knowledge and concern on green purchase intention the role of Attitude as a Mediating Variable, British Journal of Arts and Social Sciences, 7 (2): 145-167.

Angelovska, J., Sotiroska, S. B., \& Angelovska, N. (2012). The impact of environmental concern and awareness on consumer behavior, Journal of International Environmental Application \& Science, 7 (2): 406.

Das, G. (2014). Linkages of retailer awareness, retailer association, retailer perceived quality, and retailer loyalty with purchase intention: A study of Indian food retail brands. Journal of Retailing and Consumer Services, 21(3), $284-292$.

Fu, H.-H. (2009). Elucidating smoking behavior in developed and developing countries. African Journal of Business Management, 3(11), 685-694.

Gallo, F., Fossi, C., Weber, R., Santillo, D., Sousa, J., Ingram, I., ... \& Romano, D. (2018). Marine litter plastics and microplastics and their toxic chemicals components: the need for urgent preventive measures. Environmental Sciences Europe, $30(1), 13$.

Ghozali, I. (2015). Aplikasi Analisis Multivariate Dengan Program IBM SPSS 24.Semarang: Badan Penerbit Universitas Diponegoro.

Groening, C., Sarkis, J., \& Zhu, Q. (2018). Green marketing consumer-level theory review: A compendium of applied theories and further research directions. Journal of Cleaner Production, 172, 1848-1866.

Ma, G., Rau, P. L. P., \& Guo, Z. (2018). The effects of environmental awareness and consumption value on green makeup product purchase intentions. Psychology, 9(7), 1898-1916.

Han, H., Hsu, L. T. J., \& Sheu, C. (2010). Application of the theory of planned behavior to green hotel choice: Testing the effect of environmental friendly activities. Tourism management, 31(3), 325-334.

Handl, G. (2019). Marine Environmental Damage: The Compensability of Ecosystem Service Loss in International Law. The International Journal of Marine and Coastal Law, 34(4), 602-641.

Hong, J. C., Lin, P. H., \& Hsieh, P. C. (2017). The effect of consumer innovativeness on perceived value and continuance intention to use smartwatch. Computers in Human Behavior, 67, 264-272.

Hair, J., Hollingsworth, C. L., Randolph, A. B., \& Chong, A. Y. L. (2017). An updated and expanded assessment of PLSSEM in information systems research. Industrial Management \& Data Systems.

Park, H. S. (2000). Relationships among attitudes and subjective norms: Testing the theory of reasoned action across cultures. Communication Studies, 51(2), 162-175.

Ilman, N.P., Wijanarko, R., Alfata, R., Salwyn, S., \& Sura, W.B. (2017). Analisis Pengolahan Sampah Plastik Rumah Tangga dan Penerapan 3R (Reuse, Reduce, Recycle) dalam Kehidupan Sehari-hari. Artikel Ilmiah Universitas Indonesia.

Julina. (2013). Determinan Perilaku Pembelian Ekologis dan Konsekuensinya Terhadap Lingkungan: Perspektif Konsumen di Kota Pekanbaru Berdasarkan Kolektivisme, Perhatian Terhadap Lingkungan, Efektivitas Konsumen, dan Kesediaan Membayar. Kutubkhanah Jurnal Penelitian Sosial Keagamaan, 16(2), 115-126.

Luke, T.W. (2019). Have a Heart for the Holocene: The Politics of Ark Activism, Collaborative Conservation, and Sponsored Survival at Museums. Fast Capitalism 15.

Maniatis, P. (2016). Investigating factors influencing consumer decision-making while choosing green products. Journal of Cleaner Production, 132, 215-228.

Maichum, K., Parichatnon, S., \& Peng, K. C. (2016). Application of the extended theory of planned behavior model to investigate purchase intention of green products among Thai consumers. Sustainability, 8(10), 1077.

Moslehpour, M., Pham, V. K., Wong, W. K., \& Bilgiçli, İ. (2018). E-purchase intention of Taiwanese consumers: Sustainable mediation of perceived usefulness and perceived ease of use. Sustainability, 10(1), 234.

Nasution, S. R., Rahmalina, D., Sulaksono, B., \& Doaly, C. O. (2019). IbM: PEMANFAATAN LIMBAH PLASTIK SEBAGAI KERAJINAN TANGAN DI KELURAHAN SRENGSENG SAWAH JAGAKARSA JAKARTA SELATAN. Jurnal Ilmiah Teknik Industri (Jurnal Keilmuan Teknik dan Manajemen Industri), 6(2).

Noor, N. A. M., Muhammad, A., Kassim, A., Jamil, C. Z. M., Mat, N., Mat, N., \& Salleh, H. S. (2012). Creating green consumers: how environmental knowledge and environmental attitude lead to green purchase behaviour?. International Journal of Arts \& Sciences, 5(1), 55.

Paul, J., Modi, A., \& Patel, J. (2016). Predicting green product consumption using theory of planned behavior and reasoned action. Journal of Retailing and Consumer Services, 29, 123-134.

Putri, N.W.E. (2019). KOMUNIKASI SOSIAL DALAM MENSOSIALISASIKAN PENETAPAN KEBIJAKAN GUBERNUR BALI TENTANG PEMBATASAN TIMBULAN SAMPAH PLASTIK SEKALI PAKAI. Jurnal Nomosleca, 5 .

Suprapti, S. N. W. (2010). Perilaku Konsumen. Denpasar: Udayana University Press. Tamashiro, Helenita R da Silva., Silveira, José Augusto Giesbrecht da., Merlo, Edgard 
Wu, Z., Ann, T. W., \& Shen, L. (2017). Investigating the determinants of contractor's construction and demolition waste management behavior in Mainland China. Waste Management, 60, 290-300.

Xu, J., Chi, C. S., \& Zhu, K. (2017). Concern or apathy: the attitude of the public toward urban air pollution. Journal of Risk Research, 20(4), 482-498.

Yang, C., Li, J., Tan, Q., Liu, L., \& Dong, Q. (2017). Green process of metal recycling: co processing waste printed circuit boards and spent tin stripping solution. ACS Sustainable Chemistry \& Engineering, 5, 3524-34.

Yuliadi, L.P.S. (2017). Optimalisasi Pengelolaan Sampah Pesisir Untuk Mendukung Kebersihan Lingkungan Dalam Upaya Mengurangi Sampah Plastik dan Penyelamatan Pantai Pangandaran. Jurnal Pengabdian Kepada Masyarakat, 1.

Zhang, X., Stacy, E., \& Enow, B. (2019). Sustainable Consumption in Food Industry: In what stages do consumers implement sustainability in their decision making process?.

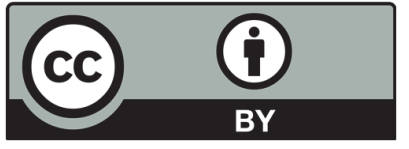

(C) 2020 by the authors; licensee Growing Science, Canada. This is an open access article distributed under the terms and conditions of the Creative Commons Attribution (CC-BY) license (http://creativecommons.org/licenses/by/4.0/). 